\title{
Thermohaline measurements in the continental shelf zone of the NW Iberian Peninsula, 1994-2006
}

\author{
J. Gago ${ }^{1,2}$, J. M. Cabanas ${ }^{1, *}$, G. Casas $^{1}$, A. Miranda ${ }^{1}$ \\ ${ }^{1}$ Instituto Español de Oceanografía (IEO), Subida a Radio Faro 50-52, 36390 Vigo, Spain \\ ${ }^{2}$ Present address: DG ENV (Marine Unit), European Commission, BU-9 3-121, 200 rue de la Loi, 1049 Brussels, Belgium
}

\begin{abstract}
From 1994 to 2006, we conducted a monthly series of CTD sampling along a coastalshelf transect, in the Ria de Vigo and the adjacent shelf (NW Iberian Upwelling System; 42 to $44^{\circ} \mathrm{N}$ and 8 to $10^{\circ} \mathrm{W}$ ). Our aim was to determine the spatial variability of the hydrographic processes over different timescales (seasonal and inter-annual) at 3 stations (ria, near-shore and shelf edge), and their relationship with other related oceanographic and climatic indices: upwelling index (UI) and North Atlantic Oscillation index (NAO). At a seasonal scale, a change in water temperature from inversion (December to February) to stratification (April to September) was found at all stations. The maximum vertical gradient in temperature is reached in July-August, coinciding with the middle of the upwelling season. The seasonal salinity cycle is influenced by continental runoff and, in winter time, by salty subtropical water carried alongshore by the Iberian Poleward Current. At an interannual scale, during spring-summer (upwelling season), in the upper layer of the ria station, a warm-

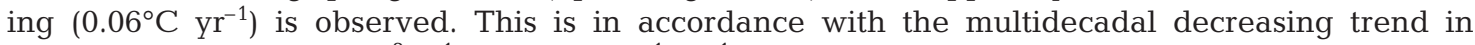
upwelling intensity $\left(\sim 5 \mathrm{~m}^{3} \mathrm{~s}^{-1} \mathrm{~km}\right.$ of coast $\left.{ }^{-1} \mathrm{yr}^{-1}\right)$ that would have favoured a warming of surface coastal waters. In contrast, a surface temperature decrease $\left(0.11^{\circ} \mathrm{C} \mathrm{yr}^{-1}\right)$ was observed at the shelfedge station in the autumn-winter period (downscaling season). We hypothesise that the observed reduction in temperature is due to the combined effect of the increase in upwelling events during the downwelling season and the decline of NAO since 1995. No significant temporal trends on an interannual scale were found in salinity values in surface or bottom layers of the stations.
\end{abstract}

KEY WORDS: Salinity $\cdot$ Temperature $\cdot$ Temporal series $\cdot$ Upwelling $\cdot$ NW Iberian Peninsula $\cdot$ Ria de Vigo

\section{INTRODUCTION}

The area studied is the western coast of Galicia, an eastern boundary upwelling system, which lies from 42 to $44^{\circ} \mathrm{N}$ and is characterised by a temperate climate, the so-called NW Iberian Upwelling System (NW IUS).

The Ria de Vigo (see Fig. 1) is one of the Baixas rias, 4 major coastal inlets formed by sunken river valleys. This upwelling ecosystem has recently been recognised as forming an intrinsic component of the 'shelf system' (Doval et al. 1998), driven by large-scale and local winds, especially during summer when freshwater input is minimum. The climate in the Galician region ( 42 to $44^{\circ} \mathrm{N}$ and 8 to $10^{\circ} \mathrm{W}$ ) can be characterised as oceanic, tending to aridity in summer (de Castro et al. 2006). The meteorological dynamics of the NW IUS region are highly conditioned by the seasonal evolution of 2 atmospheric systems, the Azores High and the Icelandic Low pressure systems that affect wind patterns over the area (i.e. of the North Atlantic Oscillation Index, NAO).

Upwelling into the Rias Baixas is generally a springsummer process characterised by upwelling-favourable northerly winds along the coast (Blanton et al. 1984), which produce an offshore zonal Ekman transport of surface water. This water is replaced by a cold nutrient-rich deep water mass called Eastern North Atlantic Central Water (ENACW) (Ríos et al. 1992). 
Conversely, during autumn-winter, favourable southerly winds are predominant, generating downwelling and a coastal poleward flow, the Iberian Poleward Current (IPC), associated with a series of mesoscale eddies (see e.g. Relvas et al. 2007, Otero et al. 2008, 2010). The warm, salty IPC flows from the central Atlantic and runs from west to east across the shelf of the Iberian western and northern Atlantic coast. See Relvas et al. (2007) for a review of the physical oceanography of the IUS, and Varela et al. (2005) for the Rias Baixas region.

In the present study, temperature and salinity data were analysed to search for significant seasonal patterns and inter-annual variability. Also, relationships to other oceanographic and climatologic properties (upwelling [UI] and NAO indices) were studied.

\section{MATERIAL AND METHODS}

\subsection{Data collection}

The present study covers 12 yr (1994 to 2006) of thermohaline data with a monthly frequency. Our timeseries dataset is one of the longest characterising the NW IUS. The transect consists of 3 sampling stations near the Ria de Vigo, covering coastal and shelf conditions. We also use some climatological indices as indicators of global oceanographic and climatic conditions in this zone of the Northeast Atlantic. From a set of regional indices, which are highly correlated with each other, we chose the NAO and the UI as representative for the climatic and hydrographic variability in the area, following Hurrel \& Dickson (2004), Cabanas \& Alvarez (2005).

A major issue in producing and using long-term data series is to assure their quality and accuracy, in order to provide homogeneous data sets. In practice, this factor is far from trivial. As the IPCC-2007 emphasised, regional analyses based on uniform methodology and a uniform database are lacking.

The Radiales Project (Valdes et al. 2002) was established by the Instituto Español de Oceanografía (IEO) in 1991 as a long-term coastal monitoring programme. Each station is sampled monthly, following standard protocols for hydrography, nutrients and plankton. A detailed description of hydrographic sampling methods is given by Gonzalez-Pola et al. (2005).

In the present study, thermohaline variables were sampled with a monthly periodicity from February 1994 to December 2006 on board the RV 'J. M. Navaz'. Conductivity, temperature and depth (CTD) profiles were taken during each survey at 3 stations situated along a transect perpendicular to the coast around $42^{\circ} \mathrm{N}$ and $9^{\circ} \mathrm{W}$, a region in the Ria de Vigo and adja- cent shelf: a ria station (Stn $1 ; 42^{\circ} 12.8^{\prime} \mathrm{N}, 8^{\circ} 51^{\prime} \mathrm{W}$; depth $40 \mathrm{~m}$ ), a near-shore station (Stn $3 ; 42^{\circ} 8.5^{\prime} \mathrm{N}$, $8^{\circ} 7.5^{\prime} \mathrm{W}$; depth $97 \mathrm{~m}$ ) located at the southern mouth of the ria, and a shelf edge station (Stn $5 ; 42^{\circ} 7.5^{\prime} \mathrm{N}$, $9^{\circ} 7.5^{\prime} \mathrm{W}$; depth $148 \mathrm{~m}$ ) (Fig. 1).

Vertical temperature and salinity profiles were obtained with CTD profilers (SB19 and SB25, SeaBird). The CTD accuracy was \pm 0.005 for salinity and $\pm 0.01^{\circ} \mathrm{C}$ for temperature. Sensors were calibrated and the collected data were corrected to eliminate any possible drift. After that, each profile was processed and averaged in $1 \mathrm{~m}$ bins. Following UNESCO guidelines (Fofonoff \& Millard 1983), salinity and sigma density $\left(\sigma\right.$-t, density $-1000 \mathrm{~kg} \mathrm{~m}^{-3}$ ) were calculated.

A historical database of upwelling indices (UI) calculated at $43^{\circ} \mathrm{N} 11^{\circ} \mathrm{W}$ since 1966 was considered (Lavin et al. 1991). In the Rias Baixas (where the shore line forms an angle of approximately $90^{\circ}$ with the equator), the cross-shore component of the Ekman transport is equal to the rate of water upwelled per kilometre of coast and expressed by UI in $\mathrm{m}^{3} \mathrm{~s}^{-1} \mathrm{~km}_{\text {of }}$ coast $^{-1}$. Positive (negative) UI values indicate conditions that are favourable (unfavourable) to upwelling, with northerly (southerly) winds. Previous studies (see e.g. Cabanas \& Alvarez 2005) have shown the correlation between zonal Ekman transport calculated at $43^{\circ} \mathrm{N} 11^{\circ} \mathrm{W}$ and near the western coast of Galicia.

NAO index data were obtained from www.cgd.ucar. edu/cas/jhurrell/indices.html. This index is based on the difference in normalised sea-level pressure between Lisbon, Portugal and Stykkisholmur/Reykjavik, Iceland for the months December to March (Hurrell \& Dickson 2004). The NAO is the dominant mode of winter climate variability in the North Atlantic region.

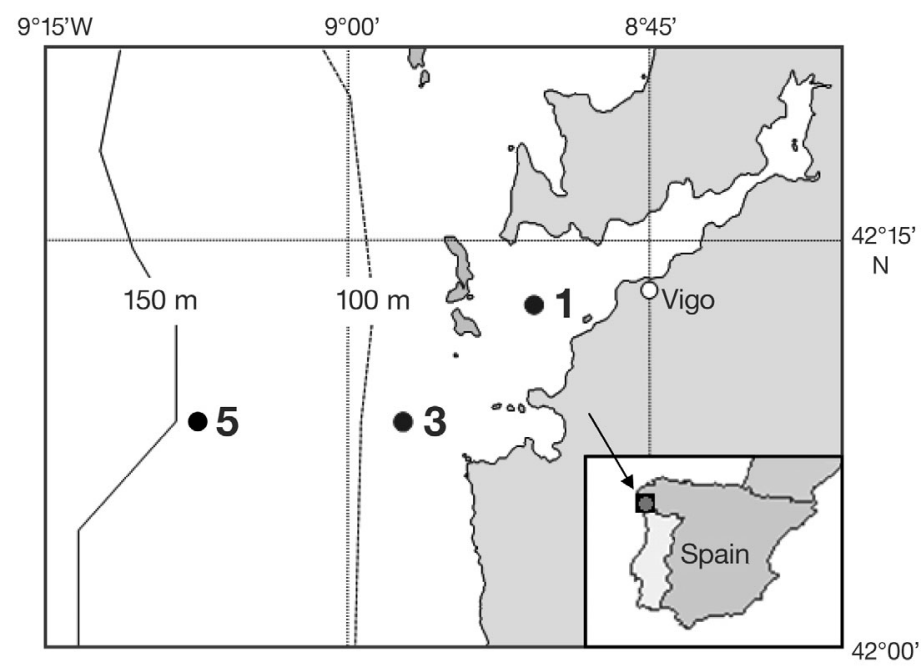

Fig. 1. Study region. Stns 1 (ria), 3 (near-shore) and 5 (shelf edge) and the 100 and $150 \mathrm{~m}$ isobaths are shown 
Under the NAO positive phase, low-pressure anomalies over the Icelandic region and throughout the Arctic combine with high-pressure anomalies across the subtropical Atlantic to produce stronger than average westerlies across middle latitudes. This phase of the oscillation is, consequently, associated with warm weather over Europe, as well as with wet conditions in northern Europe and dry conditions over southern Europe. This pattern of climate anomalies is most pronounced during winter. The opposite patterns of temperature and precipitation anomalies are typically observed during negative phases of the NAO (see e.g. Hurrel \& Dickson 2004).

\subsection{Database}

Fig. 2 shows all the salinity and temperature values used in the present study; 5178, 12488 and 11302 salinity and temperature data points were used for Stns 1, 3 and 5, respectively. The graphs also show a dashed line representing the thermohaline properties for ENACW of subtropical origin (ENACWst), as described by Ríos et al. (1992). Despite the fact that Stn 5 is deeper than Stn 3, Stn 5 has fewer data points mainly due to adverse climatological conditions that impeded sampling at the outer station in some periods.

Fig. 2 shows a gradient between the ria and the shelf edge station; while at the ria station, values of salinity $<34$ are observed, at the shelf edge station only a few values reach this level. This happens mainly in winter; a similar pattern can be observed in the values of temperature of $\sim 15^{\circ} \mathrm{C}$. a

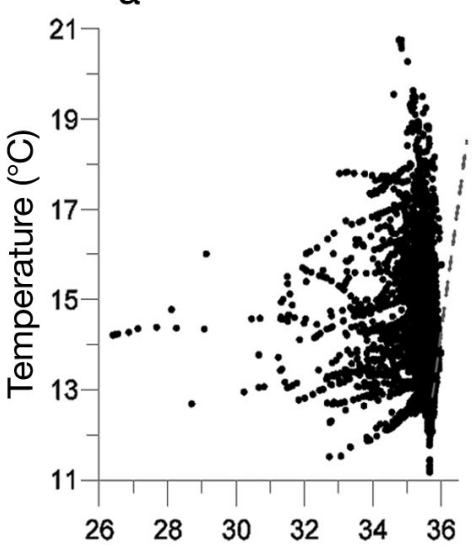

$b$

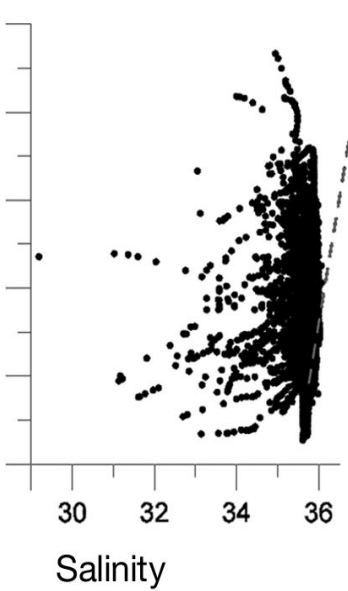

C

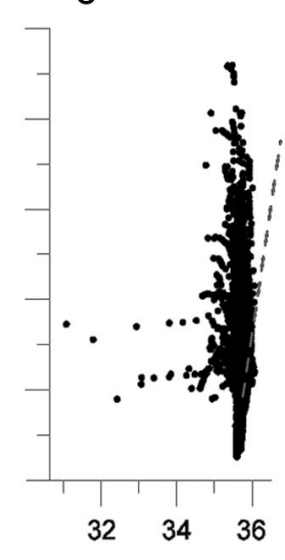

Fig. 2. Salinity and temperature data for Stns (a) 1, (b) 3 and (c) 5. Broken grey line: Eastern North Atlantic Central Water of subtropical origin (Ríos et al. 1992)

\section{RESULTS}

\subsection{Time series}

Fig. 3 shows the temporal evolution of temperature (emphasising the $15^{\circ} \mathrm{C}$ isoline) for the stations studied, and the isopycnal of 27.1 that corresponds to water of subtropical origin (ENACWst; Ríos et al. 1992).

At the ria station, a clear alternance in the $15^{\circ} \mathrm{C}$ isoline is observed. At the end of nearly every year the $15^{\circ} \mathrm{C}$ isoline is observed (Fig. 3a). A remarkable fact is the high downwelling observed during the winters of 1994, 1996, 1998, 2002, 2003 and 2006. Throughout the sampling period, the isopycnal of the ENACWst level (27.1) is only observed at the ria station in the winter of 2005, reaching nearly $20 \mathrm{~m}$ depth. This strong downwelling event is also observed at the other stations. During summer, upwelling brings colder waters to the surface and enhances stratification at the ria station.

Seasonal salinity fluctuations (associated with high autumn-spring river discharge) varied markedly at an interannual scale (Fig. 4a). The influence of the freshwater runoff was stronger at the ria station, which is closer to the river mouth. Spring 1998, autumn 2000 to spring 2001 and autumn 2003 were periods when the water-column salinity was lower. The lowest values were observed in 2001, a year with heavy rain in our time series (Otero et al. 2010). In contrast, salinity during winter 1999, spring 2002, winter 2005 and winter 2006 was closer to typical ocean values in the region.

The near-shore station had a similar downwelling pattern to the ria station (Fig. 3b). Comparing the 2 stations, it seems that the event of winter 1998 is the most intense. In the case of salinity (Fig. 4b), levels of $\leq 35$ are observed only sporadically and with a weak signal, affecting only the surface layer (only in January to February 1997 and in 2004 is an important signal observed). The ENACWst isopycnal is observed on 3 occasions at the inner shelf station, 2 in summer (1998 and 2005) and one in winter 1995, and is more notable in temperature than in salinity.

At the shelf edge station, the 35 isohaline is observed only after the high downwelling event of February 1998, probably due to the outward transport of the freshwater accumulated in the rias (Figs. 3c \& 4c). The 27.1 isoline was observed in some periods, similar to the inner shelf station. This level was only reached at depths of $<50 \mathrm{~m}$, and even at the surface, from April to June 2005. 


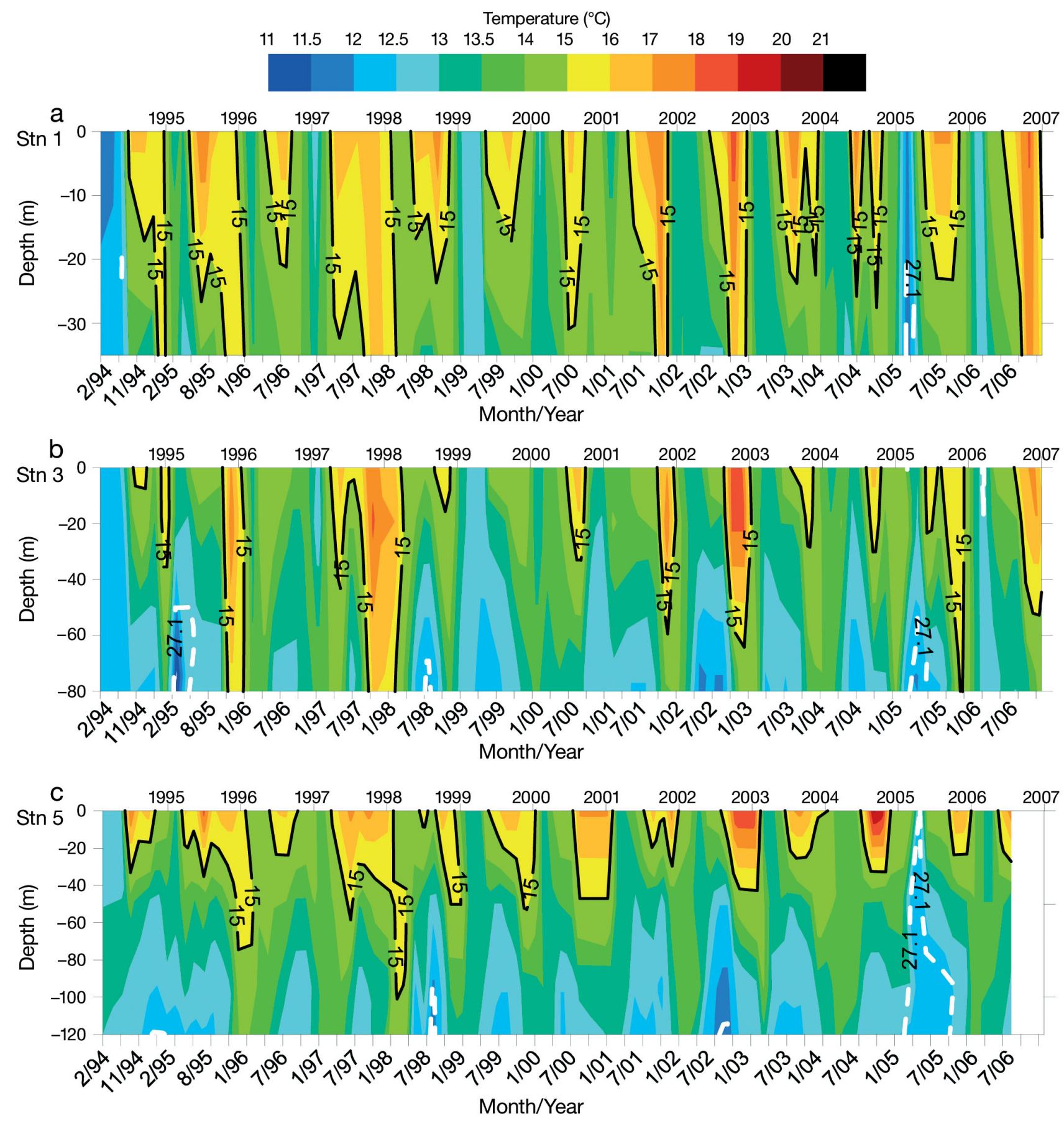

Fig. 3. Temporal evolution of temperature from February 1994 to December 2006 at Stns (a) 1 , (b) 3 and (c) 5 . The $15^{\circ} \mathrm{C}$ isolines are shown. Broken white line: Eastern North Atlantic Central Water of subtropical origin $\sigma$-t density (27.1). Blank area in (c): no data

It is noticeable that the isopycnal of 27.1 is almost observed at the shelf edge station, and that there is an important fluctuation in its seasonal appearance. In the salinity evolution it is interesting to note that there is no perfect coupling between the ria and the shelf edge station; the south winds transport warmer salty water to the north and promote the accumulation of cool fresh water in the rias. Coupling of thermohaline evolution depends on the equilibrium between these forces, the northward transport of shelf water and ria runoff. For example, the isohaline of 35 is observed in February 1998 for all 3 stations. But, surprisingly, the strongest event observed at the ria station in winter 2001 has only a weak signal at the other stations. 

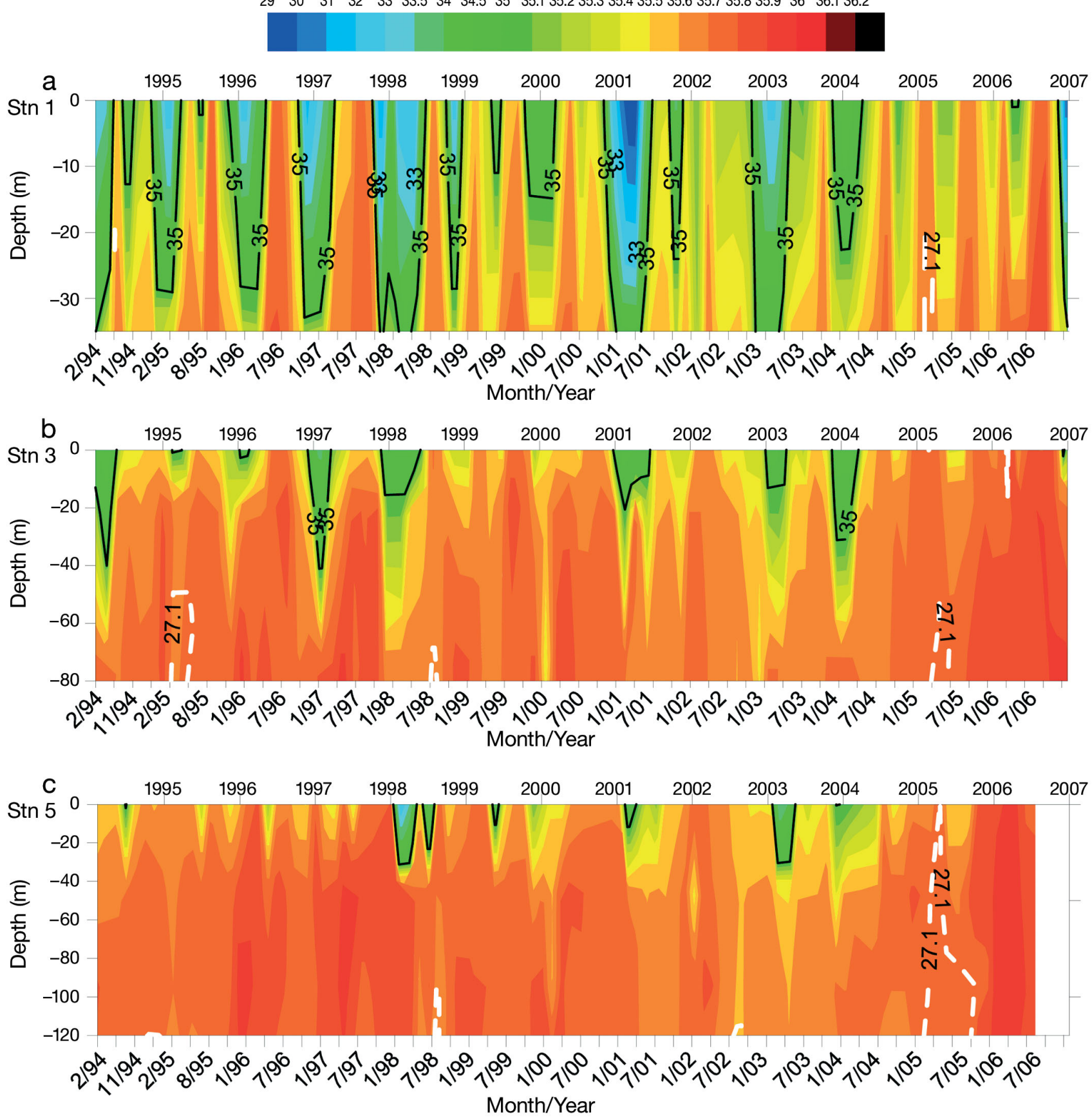

Fig. 4. Temporal evolution of salinity from February 1994 to December 2006 at Stns (a) 1, (b) 3 and (c) 5 . The salinity 33 \& 35 isohalines are shown. Broken white line: Eastern North Atlantic Central Water of subtropical origin $\sigma$-t density (27.1). Blank area in (c): no

\subsection{Seasonal evolution}

Surface temperature and salinity measurements were taken monthly (to show seasonality) at $5 \mathrm{~m}$, since warming and cooling of upper layers is efficiently resolved at this depth. At 30 and $50 \mathrm{~m}$ (for Stn 1, and Stns 3 and 5, respectively) we studied the modification of this cycle below the seasonal thermocline. Fig. 5 shows the average values and their corresponding standard deviations.

From December to March, thermal inversion takes place (higher temperatures at the bottom than in the surface layer), mainly due to IPC development and the strong decline in air temperature. The water column 

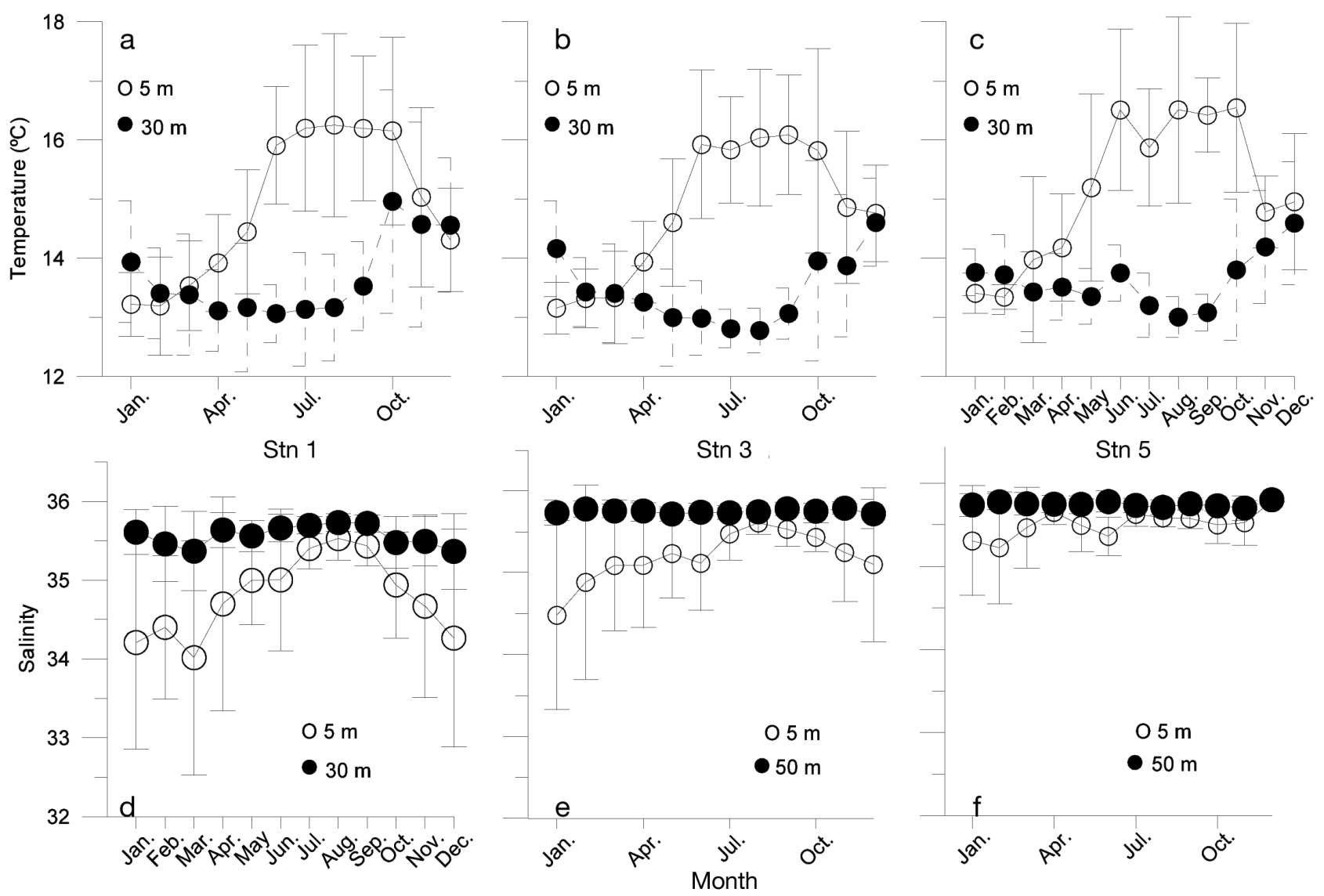

Fig. 5. Seasonal evolution of temperature for Stns (a) 1, (b) 3 and (c) 5 and salinity for Stns (d) 1, (e) 3 and (f) 5 at the surface (5 m) and bottom $(30 \mathrm{~m}$ for the ria station and $50 \mathrm{~m}$ for the other 2 stations). Error bars: $\mathrm{SD}$

becomes briefly homogeneous in early April, but quickly stratifies and remains so until December, when thermal inversion develops once more (Fig. 5a-c). It is also interesting to note the difference in thermal inversion between the ria and the shelf edge station. This is observed in December at the ria station, close to homogenisation at the near-shore station, with none at the shelf edge station. The river runoff is higher in this month and during winter, and is associated with the lower salinity of the plume, a lower temperature contributing to the observed thermal inversion.

At the shelf edge station, thermal inversion is observed in January and February, while at the ria station it is observed only in January. It should be taken into account that at the ria station the bottom level is $30 \mathrm{~m}$ and for the other 2 stations this level is $50 \mathrm{~m}$.

In the surface layer, the highest temperatures are observed in August for all stations (16.25, 16.04 and $16.51^{\circ} \mathrm{C}$ for the ria, near-shore and shelf edge stations, respectively) due to the increased radiative heating of the upper layer. The maximum difference between upper and bottom layer is also observed in this month (nearly $3^{\circ} \mathrm{C}$ at all stations).
The maximum bottom temperature for the nearshore and shelf edge stations is nearly the same (14.60 and $14.59^{\circ} \mathrm{C}$, respectively) and is reached in December, due to the IPC flow of warmer water from the south. On the other hand, at the ria station, the highest value at the bottom is observed in October $\left(15.0^{\circ} \mathrm{C}\right)$, when the transition from upwellingfavourable winds to the downwelling season takes place, maximising the residence time of the embayment waters.

With respect to salinity (Fig. $5 d-f$ ), the higher values are always observed in the bottom layer. In contrast to temperature, the higher gradient for salinity between surface and bottom is observed in winter (January and February), mainly due to continental runoff. At the ria and near-shore stations, the maximum difference between upper and bottom layers is reached in January, being 1.40 and 1.25, respectively. At the shelf edge station the greatest difference is observed in February (0.55). It must be pointed out that, mainly at the nearshore and shelf edge stations, this cool and fresher water could come from runoff from the Ria de Vigo where the main tributary is the Verdugo-Oitavén river 
or from the major tributary to the NW Iberian region, the River Miño.

The River Verdugo-Oitavén's mean daily discharge for the period 2001 to 2003 is $16.4 \mathrm{~m}^{3} \mathrm{~s}^{-1}$ (Otero et al. 2010). According to data from the national water authority (Augas de Galicia and Confederación hidrográfica del Miño-Sil), the Miño River accounts for nearly $40 \%$ of the total river water discharging onto the Galician coast (that covers $>1195 \mathrm{~km}$ ). Therefore, this represents the most important freshwater entry to the coast in this region. The River Miño's mouth is $\sim 30 \mathrm{~km}$ from the near-shore station and has a mean observed stream flow of $>300 \mathrm{~m}^{3} \mathrm{~s}^{-1}$ (Otero et al. 2010), similar to the other main river in the region, the River Duero.

Near-homogenisation of salinity in the water column is reached only in summer (July and August) at the ria and near-shore stations. At the outer station this is observed almost from August (due to upwelling) to December (winter mixing). From January to March, a slight gradient between the bottom and upper layer is observed. At this station, the highest salinity is reached in December for all averaged values at the surface (35.78) and bottom (35.80). A further aspect that emerges from Fig. $5 \mathrm{~d}-\mathrm{f}$ is the homogeneity in the bottom salinity values; the average value for the $30 \mathrm{~m}$ level (Stn 1) is $35.57 \pm 0.32$. For the other stations, at the $50 \mathrm{~m} \mathrm{level,} \mathrm{the} \mathrm{values} \mathrm{are} \mathrm{very} \mathrm{similar:} \mathrm{for} \mathrm{near-}$ shore it was $35.75 \pm 0.10$ and for the shelf edge station it was $35.74 \pm 0.10$.

According to Nogueira et al. (1997), with data from 1987 to 1996, the average seasonal cycle of continental runoff to the Rias Baixas increased from $35 \mathrm{~m}^{3} \mathrm{~s}^{-1}$ in September to $70 \mathrm{~m}^{3} \mathrm{~s}^{-1}$ in November, followed by a decrease to $63 \mathrm{~m}^{3} \mathrm{~s}^{-1}$ in January and $40 \mathrm{~m}^{3} \mathrm{~s}^{-1}$ in May. In accordance with the seasonal pattern of riverine discharge, the salinity gradient at all stations in the present study is especially pronounced during late autumn and winter. It must be also noted that in autumn, at the beginning of the IPC development, continental runoff reaches its minimum values because this is the end of the driest period of the year. A further notable aspect for the shelf edge station's bottom layer in December is the presence of the salinity maximum (35.78) due to the IPC poleward flow which transports ENACWst.

\subsection{Upwelling}

According to other authors' methods (see e.g. Bakun 1990), we grouped the zonal Ekman transport (Qx) for each year into 2 values: the upwelling season average (the average value corresponding to the months of April to September; we will refer to this as US) where upwelling is favoured, and the downwelling season average (the average value corresponding to the months of October to December for the previous year and January to March of the present year; we will refer to this as DS) where the IPC is favoured. Thus, the 2 values of the average Ekman transport are used as indices for the upwelling strength and poleward current intensity, US and DS, respectively.

In the 12 yr period considered (1994 to 2006), no significant temporal trend is observed for US and DS average index values (Fig. 6). If longer temporal scales are considered (the last $40 \mathrm{yr}$ ), in accordance with other studies for the Iberian Peninsula (Lemos \& Pires 2004), a significant slight decrease in the upwelling index (at a rate of $\sim 5 \mathrm{~m}^{3} \mathrm{~s}^{-1} \mathrm{~km}^{-1}$ coast $\mathrm{yr}^{-1}$ ) is observed during the upwelling season (regression line in Fig. 6a: UI = $-5.3 \times$ year $\left.+10780 ; \mathrm{r}^{2}=0.20, \mathrm{n}=44, \mathrm{p}<0.0022\right)$. On the other hand, over the last $40 \mathrm{yr}$, no significant tem-
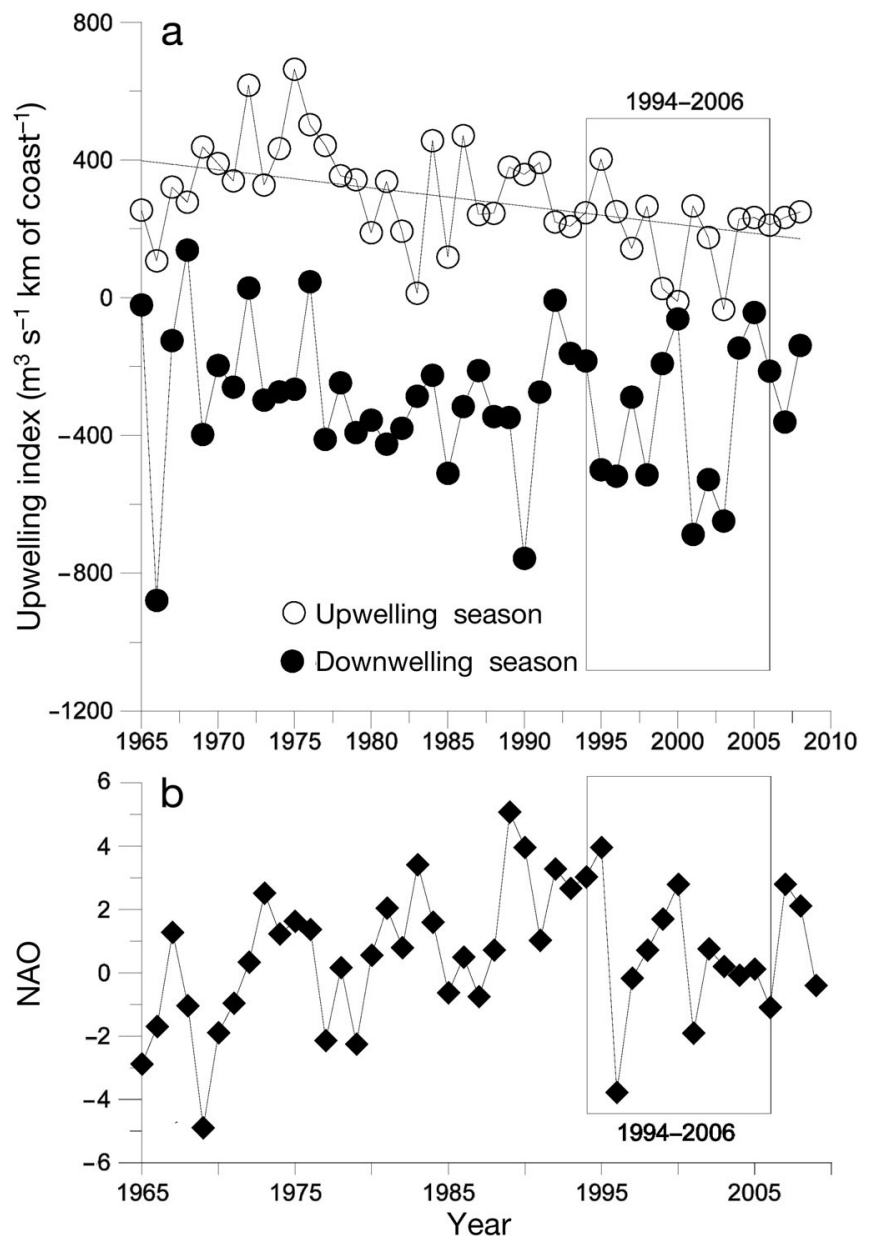

Fig. 6. (a) Annual average upwelling index for the upwelling and downwelling season from 1965 to 2009. The straight line is the trend line for the upwelling season. (b) North Atlantic Oscillation (NAO) index values (for the months DJFM) from 1965 to 2009. The boxed area is our study period (1994 to 2006) 
poral changes are observed during the downwelling season. Despite this, during the downwelling season, upwelling-favourable episodes decrease for the period 1965 to 1990 and increase from 1990 onwards, an indication of an increase of northerly winds in winter in the last 15 yr (Cabanas \& Alvarez 2005).

\subsection{Influence of atmospheric patterns}

To reflect the variability of climatic conditions in the north Atlantic, we use the winter NAO index (Hurrell \& Dickson 2004).

Although the NAO does not reflect all the climate variability over the North Atlantic, it has been related to major changes in a number of environmental variables in this region (Beaugrand et al. 2000). It is important to bear in mind that a particular effect may crucially depend on the local or regional details of the atmospheric circulation pattern that is forcing it, and that these details may not always be adequately reflected in a simple index such as the NAO.

The NAO index declined from the early 1990s until 2005-2006 (Fig. 6b). In our study period (1994 to 2006), the NAO index switched in 1995-1996 from strong positive values in the 1973-1995 period to subsequent negative values (Hurrell \& Dickson 2004). The sea surface temperature (SST) in the Eastern North Atlantic Ocean from 1990 to 2006 reflects the influence of this decline (Schuster et al. 2009), with a warming in northern latitudes, no change or a cooling in the mid-latitudes, and a warming in the tropical and eastern subtropical gyre.

\subsection{Inter-annual variability in thermohaline properties}

We used US and DS values (see Section 3.4) to assess the inter-annual variability in thermohaline properties.

Only during the period April to September (US) are significant trends observed for temperature at the ria station. No significant correlations are observed with salinity or density for the upper or bottom layer. For the other stations, no significant temporal trends are observed, either for the upper or lower layer. The increase in temperature observed in the upper layer of the nearest-to-coast station for the upwelling season is $\sim 0.6^{\circ} \mathrm{C}$ decade $^{-1}$ (regression line in Fig. 7a).

Belkin (2009) used satellite temperature data from the UK Meteorological Office (Hadley Centre, SST climatology), to show that the net SST change in the Iberian marine ecosystem was $+0.68^{\circ} \mathrm{C}$ between 1982 and 2006. For the ria station, our results (annual rate during US of $\sim 0.06^{\circ} \mathrm{C}$ between 1994 and 2006) show higher
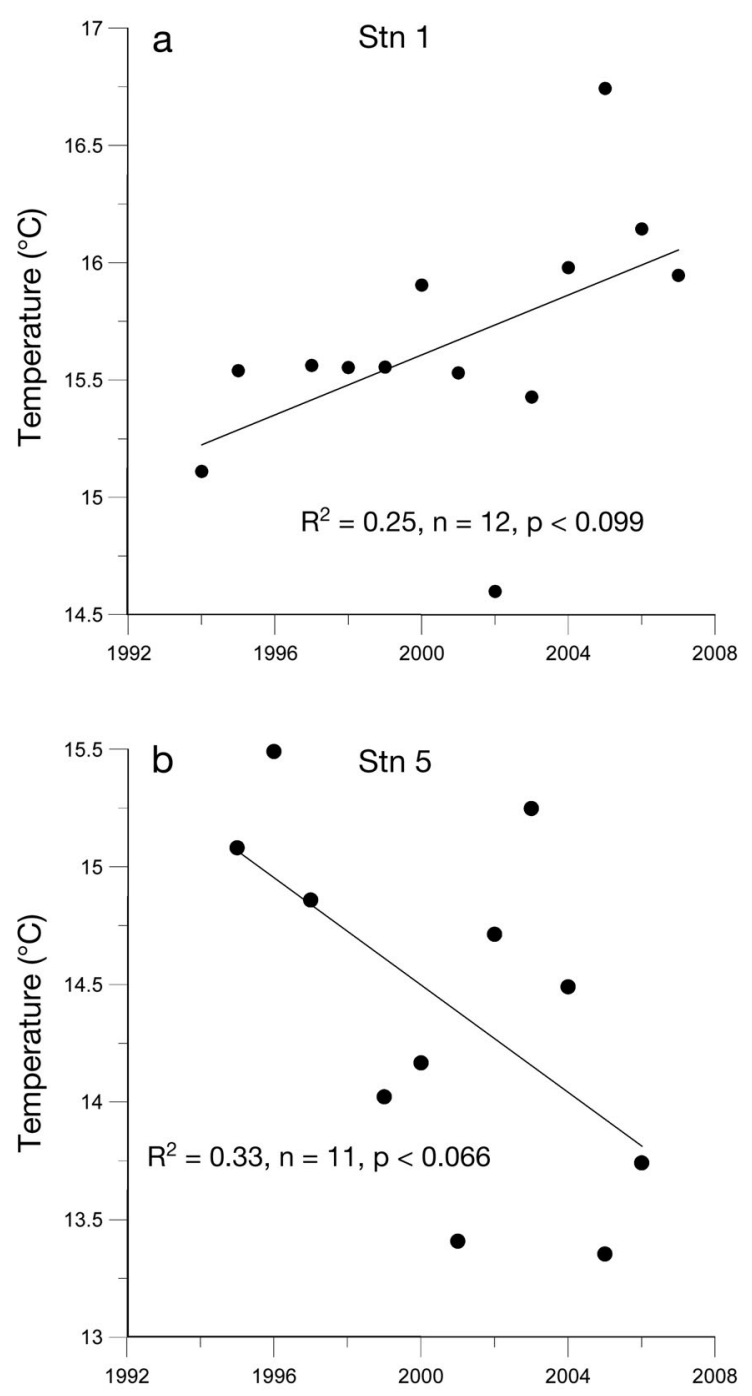

Fig. 7. Inter-annual variability (1994 to 2006) of averaged temperature of the upper layer $(5 \mathrm{~m})$ at (a) Stn 1 in the upwelling season and (b) Stn 5 in the downwelling season (solid line: the regression line)

values (more than double) than their annual average $\left(\sim 0.03^{\circ} \mathrm{C}\right)$.

On the other hand, for the shelf station in the DS, a significant decrease in temperature is observed for the upper layer (Fig. 7b), with a cooling rate of $1.1^{\circ} \mathrm{C}$ decade $^{-1}$ (regression line in Fig. 7b). This winter cooling is in accordance with the NAO negative phase (see Section 2). Similar to the upwelling season, no significant temporal trend is observed in salinity.

\section{DISCUSSION}

The temporal and spatial scales covered by this dataset provide an integrated view of the hydrographic variability in the region. 


\subsection{Upwelling season}

The decadal warming of $0.06^{\circ} \mathrm{C} \mathrm{yr}^{-1}$ that we found is similar to the warming found at higher latitudes (around $57^{\circ} \mathrm{N}$ ) by Inall et al. (2009). Those authors found warming at a rate of $0.57^{\circ} \mathrm{C}$ decade $^{-1}$ in coastal waters to the west of Scotland. The cooling during the downwelling season could counteract the increase observed in temperature at an annual scale, resulting in a lower value, and masking the effects over the year. The downwelling period corresponds to values from January to March of the corresponding year and data from October to December of the previous year. Therefore, this is not an annual average but, due to the upwelling seasonality, we consider that this better reflects the oceanographic variability of the upwellingsystem.

In addition, the warming of the sea surface (Inall et al. 2009) is accompanied by an increase in the air temperature observed at land-based coastal stations. For the period 1961 to 2006, land-based meteorological observations (Cruz et al. 2007) show a decadal increase of $0.18^{\circ} \mathrm{C}$ decade ${ }^{-1}$. This increase is not homogeneous, and there has been an abrupt change since 1972 , resulting in a decadal change of $0.36^{\circ} \mathrm{C}$. Cruz et al. (2007) observed a higher increase during springsummer, in accordance with our results for the upwelling season.

Our results during the upwelling season are in accordance with the results of Lemos \& Sansó (2006) who, when studying the Iberian region, found that overall changes were significant in coastal waters but not in offshore regions. The weakening of the upwelling regime seems to be the cause of the temperature increase in the coastal zone of the Iberian region. Therefore, due to our reduced timescale and lower effect (compared to the ria station), it is difficult to relate these effects in the outer region in our study.

Our results are also in accordance with the findings by Álvarez-Salgado et al. (2008). Those authors indicate that the reduction in upwelling intensity has caused an increase in water residence time in the Rias, promoting warming at the surface due to heating from increased irradiance. This fact reinforces the role of heating during the upwelling season.

\subsection{Downwelling season}

Although the upwelling-favourable season has been extensively studied in the Rias Baixas and the adjacent zone (Varela et al. 2005), the downwelling season has received less attention (Álvarez-Salgado et al. 2003). Although this can be called the 'non-productive season' from a biological perspective, it can strongly influ- ence the distribution of species that develops during the upwelling period (the 'productive season'); in this sense, Sordo et al. (2001) has associated the presence of harmful algae blooms (HABs) in the rias with their transport from the south (Portuguese coast) via the IPC poleward flow.

The decrease in temperature of the shelf edge sta-

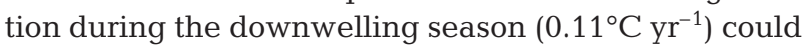
be associated with an increase in upwelling events, as indicated by Cabanas \& Alvarez (2005). According to those authors, for the last $15 \mathrm{yr}$, the frequency of observed winter upwelling events is higher due to the prevalence of northerly winds. This effect is probably masked on the coast due to the increased runoff in the winter period.

Indeed, the post-1996 cooling of our shelf edge station began nearly simultaneously with the NAO index switch in 1995-1996 from positive values, typical of the 1973-1995 period, to negative or weakly positive values afterwards. As indicated in Section 3, the decline of the NAO is associated with cooling or no change in temperature during winter in our study region.

\subsection{General remarks}

The distinct behaviour of coastal and offshore water during US is, in part, due to the long-term warming of the former, as previously pointed out by Lemos \& Pires (2004). Our results are in accordance with the study of Lemos \& Sanso (2006); those authors found that coastal SST increased by $1^{\circ} \mathrm{C}$ in a century, nearly 5 times higher than in the ocean region. In any case, our observed increase in the coastal zone is almost 6 times higher than that observed by Lemos \& Sanso (2006). This could be related to the existence of the rias in the Galician region that increase the residence time of waters in the coastal region compared to the Portuguese coast.

Changes in the phytoplankton community observed by Bode et al. (2009) are in accordance with our results showing an increase in the temperature in the upper layer of the ria station during US (the 'productive season'). Those authors found that diatom dominance decreased in recent years in the NW Iberian region, particularly offshore. In turn, the abundance of dinoflagellates increased, notably on the coast. They found that zooplankton abundance (mainly copepods) significantly decreased offshore, but increased near the coast.

Diatoms, although still dominating blooms in shelf waters, are giving way to dinoflagellates, which are more adapted to weakly stratified waters (Margalef 1956). Also, stratification may limit primary production, as nutrient inputs from deep waters are reduced. 
Valdes et al. (2007) reported a significant reduction in primary production values in the Bay of Biscay in the period 1993 to 2003.

Despite the present study results in temperature change being similar to those found in boreal ecosystems, the effect on ecosystem structure is not related to that observed in the latter. In general, a rapidly warming environment would be expected to result in a poleward movement of species. Nogueira et al. (2000) concluded that meteorological and thermohaline disturbances operating at intermediate frequency during the 'productive season' in the Ria de Vigo allowed the maintenance of plankton assemblages with relatively high functional diversity, thus preventing competitive exclusion.

\section{CONCLUSIONS}

Oceanographic monitoring programmes based on regular records of water-column profiles have proven to be particularly valuable. Time-series programmes are extraordinarily difficult to maintain and few survive for periods longer than a decade (Duarte et al. 1992). In this sense, the Radiales Project has been a successful initiative, and continues its work.

As expected, the annual sequence of upper-layer temperature and salinity values in our study region is characterised by a temperate seasonal cycle (Figs. 4 \& 5). On mid-latitude continental shelves, the net surface heat flux changes from cooling to warming in spring, in response to air warming and an increase in the temperature of continental runoff (He \& Weisberg 2002).

Temperature shows a different pattern in the upwelling and downwelling seasons. In the upwelling season, a warming - related to wind-driven upwelling decrease - is observed at the upper layer of the ria station $\left(0.06^{\circ} \mathrm{C} \mathrm{yr}^{-1}\right)$. The multidecadal decreasing trend in upwelling intensity (at a rate of $\sim 5 \mathrm{~m}^{3} \mathrm{~s}^{-1} \mathrm{~km}$ of coast ${ }^{-1} \mathrm{yr}^{-1}$ ) during the upwelling season, and the consequent reduction in offshore transport of surface water, would have favoured a warming of surface waters in the coastal zone.

The decrease in upwelling during the last $40 \mathrm{yr}$ has been related to an increase in the renewal time of water inside the Galician Ria, which was also related to an increase in the occurrence of HABs (Álvarez-Salgado et al. 2008). On the other hand, the temperature increase at the ria station is in accordance with the general trend (see e.g. IPCC 2001) whereby the impact of climate change on ecosystems will be stronger for enclosed areas than for open seas.

Despite no significant temporal trend being observed in the averaged upwelling index for the downwelling period during the last $40 \mathrm{yr}$, an important fact is the increase in upwelling events in winter over the last $15 \mathrm{yr}$ (Cabanas \& Alvarez 2005). In addition, the decrease in the NAO index (since 1995) promotes a cooling in air temperature in the region during winter time. This causes a cooling $\left(0.11^{\circ} \mathrm{C}^{-1}\right)$ in the upper layer of the shelf edge station.

One should be cautious of a long-term interpretation of our results in temperature and salinity evolution, since we studied a period of only $12 \mathrm{yr}$. On the other hand, despite its local relevance, our study could be interesting at a larger geographical scale, at least to the Iberian upwelling system.

Acknowledgements. This work was supported by the Instituto Español de Oceanografía (Project Radiales) and is a contribution to the GLOBEC-Spain Programme. We are very grateful to the 3 reviewers who made a number of useful suggestions to improve this paper. We express our sincere thanks to many colleagues who made this study possible, and especially to the crew of RV 'J. M. Navaz'.

\section{LITERATURE CITED}

Álvarez-Salgado XA, Figueiras FG, Pérez FF, Groom S and others (2003) The Portugal coastal counter current off NW Spain: new insights on its biogeochemical variability. Prog Oceanogr 56:281-321

Álvarez-Salgado XA, Labarta U, Fernandez-Reiriz MJ, Figueiras FG and others (2008) Renewal time and the impact of harmful algal blooms on the extensive mussel raft culture of the Iberian coastal upwelling system (SW Europe). Harmful Algae 7:849-855

Bakun A (1990) Global climate change and intensification of coastal upwelling. Science 247:198-201

> Beaugrand G, Ibanez F, Reid PC (2000) Spatial, seasonal and long-term fluctuations of plankton in relation to hydroclimatic features in the English Channel, Celtic Sea and Bay of Biscay. Mar Ecol Prog Ser 200:93-102

Belkin IM (2009) Rapid warming of large marine ecosystems. Prog Oceanogr 81:207-213

Blanton JO, Atkinson LP, Castillejo FF, Lavín A (1984) Coastal upwelling off the Rias Bajas, Galicia, Northwest Spain. I. Hydrographic studies. Rapp P-V Reun Con Int Explor Mer 183:79-90

Bode A, Alvarez-Ossorio MT, Cabanas JM, Miranda A, Varela $M$ (2009) Recent trends in plankton and upwelling intensity off Galicia (NW Spain). Prog Oceanogr 83:342-350

> Cabanas JM, Alvarez I (2005) Ekman transport patterns in the area close to the Galician coast (NW, Spain). J Atmos Ocean Sci 10:325-341

Cruz R, Lago A, Lage A, Salsón S, Pérez-Muñuzuri V (2007) Trends of temperature and precipitation daily extreme values in Galicia (Northwest Spain) over the second half of the 20th century. 7th EMS Annu Meet and 8th Eur Conf Appl Meteorol, El Escorial, Spain

deCastro M, Lorenzo N, Taboada JJ, Sarmiento M, Álvarez I, Gómez-Gesteira M (2006) Influence of teleconnection patterns on precipitation variability and on river flow regimes in the Miño River basin (NW Iberian Peninsula). Clim Res 32:63-73

Doval MD, Nogueira E, Pérez FF (1998) Spatio-temporal variability of the thermohaline and biogeochemical properties and dissolved organic carbon in a coastal embayment 
affected by upwelling: the Ría de Vigo (NW Spain). J Mar Syst 14:135-150

Duarte CM, Cebrian J, Marba N (1992) Uncertainty of detecting sea change. Nature 356:190

Fofonoff NP, Millard RC (1983) Algorithms for computation of fundamental properties of seawater. UNESCO Tech Pap Mar Sci 44. UNESCO, Paris

Gonzalez-Pola C, Lavín A, Vargas-Yañez M (2005) Intense warming and salinity modification of intermediate water masses in the southeastern corner of the Bay of Biscay for the period 1992-2003. J Geophys Res Oceans 110:C05020 doi:10.1029/2004JC002367

He R, Weisberg RH (2002) West Florida shelf circulation and temperature budget for the 1999 spring transition. Cont Shelf Res 22:719-748

Hurrell JW, Dickson RR (2004) Climate variability over the North Atlantic. In: Stenseth NC, Ottersen G, Hurrell JW, Belgrano A (eds) Marine ecosystems and climate variation - the North Atlantic. Oxford University Press, Oxford, p 15-31

Inall M, Gillibrand P, Griffiths C, MacDougal N, Blackwell K (2009) On the oceanographic variability of the North-West European Shelf to the West of Scotland. J Mar Syst 77: $210-226$

IPCC (Intergovernmental Panel on Climate Change) (2001) Watson RT, Core Writing Team (eds) Climate change 2001: synthesis report. Cambridge University Press, Cambridge

IPCC (2007) Climate change 2007: the physical science basis. Contribution of Working Group I to the Fourth Assessment Report of the Intergovernmental Panel on Climate Change. Cambridge University Press, Cambridge

Lavin A, Diaz del Rio G, Cabanas JM, Casas G (1991) Afloramiento en el Noroeste de la Peninsula Iberica. Indices de afloramiento para el punto 43 N 11 W. Periodo 1966-1989. Inf Téc Inst Esp Oceanogr 91:1-40

Lemos RT, Pires HO (2004) The upwelling regime off the west Portuguese coast, 1941-2000. Int J Climatol 24:511-524

Lemos RT, Sansó B (2006) Spatio-temporal variability of ocean temperature in the Portugal current system. J Geophys Res Oceans 111:C04010 doi:10.1029/2005JC003051

Margalef R, Durán M, Saiz F, Lopez JJ (1956) El fitoplancton de la Ría de Vigo de abril de 1954 a junio de 1955. Inv Pesq 4:67-95

Submitted: March 24, 2010; Accepted: September 29, 2010
Nogueira E, Perez FF, Rios AF (1997) Seasonal patterns and long-term trends in an estuarine upwelling ecosystem (Ría de Vigo, NW Spain). Estuar Coast Shelf Sci 44:285-300

> Nogueira E, Ibanez F, Figueiras FG (2000) Effect of meteorological and hydrographic disturbances on the microplankton community structure in the Ria de Vigo (NW Spain). Mar Ecol Prog Ser 203:23-45

Otero P, Ruiz-Villarreal M, Peliz A (2008) Variability of river plumes off Northwest Iberia in response to wind events. J Mar Syst 72:238-255

Otero P, Ruiz-Villarreal M, Peliz A, Cabanas JM (2010) Climatology and reconstruction of runoff time series in northwest Iberia: influence in the shelf buoyancy budget off Ria de Vigo. Sci Mar 74:247-266

Relvas P, Barton ED, Dubert J, Oliveira P, Peliz A, da Silva JCB, Santos AMP (2007) Physical oceanography of the western Iberia ecosystem: latest views and challenges. Prog Oceanogr 74:149-173

- Ríos A, Perez FF, Fraga F (1992) Water masses in the upper and middle North Atlantic Ocean east of the Azores. DeepSea Res A 39:645-658

Schuster U, Watson AJ, Bates NR, Corbiere A and others (2009) Trends in North Atlantic sea-surface $\mathrm{fCO}_{2}$ from 1990 to 2006. Deep-Sea Res II 56:620-629

Sordo I, Barton ED, Cotos JM, Pazos Y (2001) An inshore poleward current in the NW of the Iberian Peninsula detected from satellite images, and its relation with $G$. catenatum and $D$. acuminata blooms in the Galician Rias. Estuar Coast Shelf Sci 53:787-799

Valdes L, Lavín A, Fernandez de Puelles ML, Varela M and others (2002) Spanish ocean observation system. IEO core project: studies on time series of oceanographic data. In: Fleming NC et al. (eds) Operational oceanography: implementation at the European and regional scales. Elsevier Oceanogr Ser 66:99-105

> Valdes L, López-Urrutia A, Cabal J, Alvarez-Ossorio M and others (2007) A decade of sampling in the Bay of Biscay: What are the zooplankton time series telling us? Prog Oceanogr 74:98-114

> Varela RA, Roson G, Herrera JL, Torres-Lopez S, FernandezRomero A (2005) A general view of the hydrographic and dynamical patterns of the Rias Baixas adjacent sea area. J Mar Syst 54:97-113

Proofs received from author(s): June 24, 2011 